DOI https://doi.org/10.18551/rjoas.2021-03.17

\title{
HOUSEHOLD INDUSTRY OF CHICKEN GUT CHIPS AND ITS ROLE IN INCREASING FAMILY INCOME AT SIDOWUNGU GRESIK OF EAST JAVA, INDONESIA
}

\author{
Pudjowati Juliani*, Wahyuni Susi Tri, Asivah Lilis Iva Nur \\ Study Program of Development Economics, Faculty of Economics and Business, \\ University of Bhayangkara Surabaya, Indonesia \\ *E-mail: juliani@ubhara.ac.id
}

\begin{abstract}
This research is based on the background of the authors' observation of the business role of the IRT (Home Industry) chicken intestinal chips in Sidowungu Village with all available efforts. The author took the location in Sidowungu Village because in that location many IRTs made chicken intestinal chips as a form of family business to increase family income. The population of this study was 18 people consisting of owners of chicken intestinal chips IRT. From this study it was found that IRT making chicken intestine chips in Sidowungu Village was a business that almost all of them had long been established. This chicken intestinal chips IRT has a role to help family income, reduce unemployment and improve people's welfare. However, the efforts made by IRT chicken intestine chips in Sidowungu Village in processing are still very simple or still using traditional tools and limited marketing range, which is still within the village scope. The chicken intestinal chips IRT felt a lack of support and the role of the Government on the chicken intestinal chips IRT in Sidowungu Village; this was evident because of the lack of capital assistance, production equipment and capacity training and guidance felt by government intestinal chicken chips IRT.
\end{abstract}

\section{KEY WORDS}

Home industry, revenue, industry, role.

Industrialization is considered as a "panacea" to overcome the problem of economic development in developing countries the wisdom taken is often imposed, in the sense of simply mimicking the pattern of development policy in developed countries regardless of the circumstances and environmental conditions that exist such as the issue of raw material availability, availability of technology, labor proficiency, capital adequacy, and so on. The most tangible development results that can be seen in developed countries and widely used as a mirror of development patterns by developing countries is the level of economic industry that is considered a source of wealth, strength and balanced state of developed countries. On that basis, it is not surprising that as a poor country considers that the development of the industrial sector is a very powerful remedy to improve the situation (Sattar, 2018; 173).

The development of the industrial sector has succeeded in bringing about fundamental changes in the National economy. The increase in industrial sector contribution is relatively higher when compared to the growth rate of other sectors. The existence of industrialization itself has a strategic role to support sustainable economic growth and increase people's income through the breadth of business and employment opportunities, as well as encourage regional development and poverty alleviation. Development for industrial purposes is also a resource that can increase the economy or income, but it must also be supported by the availability of economic resources, both natural resources, human resources, and productive capital resources. In other words, without a strong enough support capacity from productive economic resources, the development in industrial activities also has difficulty in mining the economy or income.

According to Fuad et al $(2017 ; 133)$, income is a certain amount of money or something that can be measured by money, which is used to meet the needs of hiudp, or for consumption. Income is purchasing power, anyone who has no income means they have no purchasing power, and that means they are poor. In the logic of capitalism, people who do not have purchasing power have no benefit to the company. One of the problems that is 
often faced by every household or family is the small income and the amount of expenditure. This demands that each individual think about increasing his or her income.

According to Law No. 3 of 2014 on industry, industry is a business or activity of processing raw materials or semi-finished goods into goods that have added value to benefit. Industrial results are not only in the form of goods but also in the form of services. While the version of the Central Bureau of Statistics (2017) Indutrsi can be classified based on the number of workers and the amount of investment. Processing Industry Company is divided into 4 (four) groups, namely: the number of workers 1-4 people for the household industry, the number of workers 5-19 people for small industries, the number of workers 20-99 people for medium industries, the number of workers $\geq 100$ people for large industries.

According to Kimbal $(2015 ; 44)$, the understanding of the household industry is a family activity, namely as consumptive and productive units consisting of at least two members of the same household, both bearing work, food and shelter.

The household industry is usually built in an area close to the raw materials that become the raw materials of the industry. In order to improve the welfare of the community, the household industry has a very strategic role considering its various potentials. These potentials include the number of household industries and their spread, the absorption of labor, the use of local raw materials, and their presence in all sectors of the economy. The existence of household industry in the village has an important meaning in the framework of national development. Because of the existence of the household industry is a solution for the undeveloped workforce and economic improvement of the village community. However, the strategic position of the household industry in various places has not been supported by facilities and infrastructure that can improve the effectiveness and efficiency of rural economic life.

In Gresik regency located in East Java Province has several small industries or household industries such as krawu rice household industry, opaque clasp, otak-otak bandeng, pudak gresik, tengiri crackers, various fish crackers, ceker chips and chicken intestine chips. In this case researchers are interested in the household industrykeripik chicken intestines located in the village of Sidowungu District Menganti Gresik which is one of the superior products.

Sidowungu Village is a village in Menganti Subdistrict Gresik, East Java Province, Indonesia. Sidowungu is often known as "Mboro" which has a myriad of local potentials. The economic potential that we can see directly is the chicken market on the east side of the office / village hall, in Sidowungu Village most of the women work as housewives and her husband works as a chicken trader, ranging from business owners, laborers, to chicken retailers. And chicken slaughterhouses can be seen when entering the village road, along the road Sidowungu village there are many household industries that have usefulness. Another result of the existence of chicken slaughterhouses is chicken intestines that become waste that is usually disposed of (http://mengantiline.blogspot.com).

Seeing that some housewives in the village of Sidowungu Menganti Subdistrict Gresik district utilize the waste leftover chicken slaughter into food products that are high selling value, chicken waste in the form of intestines is processed into crispy gut chips and valuable selling economically enough to increase the income of families in the village of Sidowugu Menganti District Gresik.

Sidowungu villagers on average make a household business of chicken gut chips to meet the needs of life. The number of household industry chicken gut chips in Sidowungu Village as many as 18 (eighteen) industrial businesses. From industrial businesses that are more than 15 (fifteen) years old to developing ones. The existence of chicken gut chips household industry in Sidowungu Village is expected to bring changes in people's socioeconomic life that continues to develop better in order to increase family income. Thus giving rise to a new social order, namely micro-industrial community groups.

The household industry of chicken gut chips in Sidowungu Village is developing quite well because the household industry of chicken gut chips provides opportunities and economic income for families. The household industry of chicken gut chips in the field of food 
becomes one of the business options that are attractive to the community, especially entrepreneurs in Sidowungu Village.

The household industry of chicken gut chips in Sidowungu village has the potential to be developed. Because it not only plays a role in economic income for families, but also plays a role in the provider of jobs. household business of chicken gut chips in Sidowungu Village has developed quite well until now. This is seen by the many household industries standing chicken gut chips scattered in various places in the village of Sidowungu. The domestic business of chicken gut chips has become the business of most local people.

In addition to the development of the chicken gut chips household industry, the home industry always faces a variety of problems or difficulties in developing its business, problems that are always faced by the household industry chicken gut chips are usually related to the lack of role or response from the Government in the facilities and infrastructure to develop the household industry chicken gut chips, and the inability of the people of Sidowungu Village to meet financial obligations such as limited capital, lack of skills and knowledge training on the availability of existing human resources, management of production results are less maximal where the products produced are less innovative and promotions carried out are still limited to the scope of the village. This is because the knowledge that household industry owners have chicken gut chips is very lacking and limited.

Problem Formulation. Based on the background description above, it is necessary to ask the following research questions:

- What is the role of the chicken gut chips household industry in increasing family income in Sidowungu Village?

- How are the efforts of the chicken gut chips household industry in increasing the income of families in Sidowungu Village?

- What is the role of the Government in the household industry of chicken gut chips in Sidowungu Village?

Based on the above problem formulation, this study aims as follows:

- To find out how the domestic industry role of chicken gut chips in increasing family income in Sidowungu Village, Menganti District, Gresik;

- To find out how the household industry efforts chicken gut chips in increasing the income of families in the village of Sidowungu Menganti District Gresik;

- To find out how the role of the Government in the household industry of chicken gut chips in the village of Sidowungu Menganti Subdistrict Gresik.

\section{LITERATURE REVIEW}

According to Law No. 3 of 2014 concerning industry, industry is a business or activity of processing raw materials or semi-finished goods into goods that have added value for profit. Industrial products are not only in the form of goods but also in the form of services.

According to Fattah and Purwanti $(2017 ; 5)$, industry has the same meaning as a factory or company. Microeconomic theory views that industry has a different meaning from a company or firm. A company is a business entity that uses production factors to produce goods needed by the community. Industry is a collection of companies or firms that produce the same or simultaneously goods in a market, the discussion on industrial management, the term between industry and company is the same.

According to the Central Statistics Agency (2017), Industry can be classified based on the number of workers and the amount of investment. Processing Industry Companies are divided into 4 groups, namely:

a. Large Industry is a company that has a workforce of 100 people or more;

b. Medium Industry is a company with a workforce of 20 to 99 people;

c. Small Industry is a company with a workforce of 5 to 19 people;

d. Meanwhile, Home Industry is a company with a workforce of 1 to 4 people. 
According to Kimbal $(2015 ; 44)$, the definition of home industry is a family activity, namely as consumptive and productive units consisting of at least two members of the same household, equally bear work, food and shelter.

According to the Food and Drug Administration of the Republic of Indonesia (BPOM $\mathrm{RI}$ ), a home industry is a food company that has a residential place of business with manual to semi-automatic food processing equipment. At BPOM RI, the home industry that processes something derived from living or water is called the food household industry (IRTP). The characteristics of the food household industry according to BPOM RI are:

a. Industrial activities are carried out in households;

b. The workforce employed is not more than 4 people;

c. Processing equipment used ranges from manual to semi-automatic.

The household actor that is meant is the consumption household, that is, both individuals and groups whose purpose is to use or use goods or services. In a family household, there are production factors in the form of labor and capital. This production factor is sold by family households to corporate households for compensation or rewards in the form of wages and salaries as well as interest and rent. Household groups carry out basic activities, including (Sattar 2018; 20):Menerima penghasilan dari para produsen/perusahaan yang berupa sewa, upah and gaji, bunga and laba.

a. Receive income from financial institutions in the form of interest on their deposits;

b. Running this income in the goods market (as a consumer);

c. Set aside the rest of the income to be saved in financial institutions;

d. Paying taxes to the government;

e. Enter the money market as buyers, because of their need for cash for day-to-day transactions.

Humans usually have certain behaviors. Likewise in organizations, certain management usually has certain patterns of behavior. For example, a finance director is expected to have a pattern of behavior or a behavioral response expected of him or her that is his social role. According to Supriyono $(2018 ; 23)$, roles are the various parts of the game played by humans in their interactions with other people, while social roles are determining the rights, duties, obligations and behavior of humans who hold certain positions in certain social contexts.

Roles distinguish human behavior who occupy certain organizational positions and serve their group members by providing certain functions, whereas norms are the expectation of appropriate behavior for a particular role. Each role has been assigned an individual identity that shows who they are and how they should act in certain situations.

Humans may have a wide variety of roles and identities. This can create role conflicts. Role conflict occurs when someone occupies a position that is not suitable for him or when someone occupies a position that is not in accordance with the expected behavior. One important aspect of role theory is that identity and behavior are socially given and ongoing (Supriyono, 2018; 24).

According to Idris $(2016 ; 8)$, a role can be defined as typical behavior that characterizes each person in a work group or social context that has a major influence on an event. Role is very important because it can regulate one's behavior.

According to Fuad et al $(2017 ; 133)$, income is an amount of money or something that can be measured in money, which is used to meet life needs, or for consumption. Income is purchasing power, whoever has no income means they do not have purchasing power, and that means they are poor. In the logic of capitalism, people who do not have purchasing power are of no benefit to the company. Income is the total income (money and not money) of a person or household during a certain period. Income is a flow concept. There are three sources of income (Rahardja, 2010; 293):

- Income from Salaries and Wages Salaries and wages are remuneration for willingness to work as workers. The theoretical amount of a person's salary / wages is very dependent on his productivity; 
- Income from Earning Assets Earning assets are assets that provide income for service use. There are two groups of productive assets. First, financial assets (Financial assets);

- Revenue from the Government Revenue from the government or transfer receipts is income received not as remuneration for the input given.

According to Lubis $(2018 ; 5)$, the family is the smallest institution of society or the nation, the family is at the same time the most important center of education in whole human development. It is the family that shapes the character, morals and personality of individuals who are displayed in religious attitudes or behaviors both in the form of spiritual keshalehan and social piety.

According to Rifai $(2010 ; 52)$, the conjugal system emphasizes the importance of marital relationships (between husband and wife), ties with husbands or wives tend to be considered more important than ties with parents.

The family can also be defined as a group of people who are united by ties of marriage, blood or adoption, constituting their own household structure, interacting and communicating with each other which create social roles for husband and wife, father and mother, son and daughter, brothers and sisters and the maintenance of a common culture.

\section{METHODS OF RESEARCH}

In this study, the approach used by the researcher is a qualitative approach method where the qualitative research method is a research method based on the philosophy of postpositivism, used to examine the conditions of natural objects, (as the law is an experiment) where the researcher is the key instrument, the data collection technique conducted in triangulation (combined), data analysis is inductive / qualitative, and the results of qualitative research emphasize meaning more than generalization (Sugiyono, 2017; 9).

In this study, the researcher tries to describe the object and subject under study in accordance with what it is, with the aim of systematically describing the facts and characteristics of the object under study accurately. This is to understand the phenomena that occur in the intestinal chip home industry in the village, such as application, perception and description in the form of words and documents.

\section{RESULTS AND DISCUSSION}

Overview of Sidowungu Village. Sidowungu is a village name in the District of Menganti, Gresik Regency, East Java Province. Geographically, Sidowungu Village is located at a position of 7.1 South Latitude and 12.1 East Longitude. The topography of the height of this village is in the form of medium land, which is about 3 meters above sea level. Based on BPS data for Gresik Regency in 2018, during 2018 the average rainfall in Sidowungu Village reached $1,521 \mathrm{~mm}$. The most rainfall occurs in January-February.

The distance from Sidowungu Village to the District Capital is $2 \mathrm{Km}$, which can be reached in about 15 minutes, while the distance to the district capital is $30 \mathrm{~km}$, which can be reached in about 1.5 hours. The area of Sidowungu Village is 316,272 hectares and the boundaries of Sidowungu Village are:

- West side: Bordering Randupadang Village;

- East side: Bordering Setro Village;

- North: Bordering Wedoroanom Village;

- South side: Bordering Hulaan Village.

The number of Hamlet / Neighborhood, Sidowungu Village is divided into 6 Rukun Warga (RW) and 25 Rukun Tetangga (RT), as follows:

a. Sidowungu Hamlet: 4 RW and 16 RT;

b. Dusun Balong Dinding: 2 RW and 9 RT.

With an area of about 316,272 hectares Sidwoungu Village, Sidowungu Village has a population of around 7,680 people with $\pm 2,107$ heads of households. 
Home Industry Profile in Sidowungu Village. Sidowungu Village is a village that is part of the Menganti District, Gresik Regency. The majority of the population in this village is involved in home industry and agriculture. One of them is the intestinal chips industry, which the majority of the people in Sidowungu Village are involved in. The availability of raw materials causes this industry to progress and develop both in terms of quality and quantity.

Sidowungu Village is the largest intestinal producing area in Gresik Regency. This home industry business in Sidowungu Village has been around since 2000. This proves that this business has a very advanced prospect. In addition, because the raw materials are obtained from the area itself. This is something that is very supportive of these production activities. Not only that, this business is often occupied by the local community or is often referred to as a home industry that makes food from chicken intestines, for example intestinal chips, intestinal satay, spicy intestines and so on.

The intestinal chips industry business continues to experience development. Residents in Sidowungu Village are increasingly interested in establishing a intestinal chip business because they see a promising prospect and the success of the existing home industry. In early 2005 Mrs. Nur Rohima established a home industry for intestinal chips, after producing and experiencing development, in $2007 \mathrm{Mrs}$. Sayutik was interested in establishing the same business seeing the development of the business founded by Ms. Nur Rohima. From 2005 to 2019, 16 similar businesses have been established, due to the large opportunity for this business to meet the economic needs of its owners.

In addition to the development of the intestinal chips home industry, other industries such as peanut brittle, tempeh, lento and onion crackers have also developed. Until now, there are 18 business units in the intestinal chips home industry.

The Role of Chicken Intestinal Chips Home Industry in Increasing Family Income in Sidowungu Village. According to Idris (2016; 8), a role can be defined as typical behavior that characterizes each person in a work group or social context that has a major influence on an event. The role is very important because it can regulate a person's behavior. Meanwhile, according to Supriyono $(2018 ; 23)$, role is the various parts of the game played by humans in their interactions with other people, while social role is the determination of rights, duties, obligations and human behavior. who hold a certain position in a certain social context.

The existence of this intestinal chips home industry plays a very big role in improving the welfare of the people of Sidowungu Village because by entrepreneurship, selling chicken waste products in the form of intestines to be used as intestinal chips can increase income and can meet family needs and reduce unemployment. Increasing family income is a solution in overcoming economic instability due to lack of income. In this case, the wife's role as a housewife must be very clever in managing. If this is not sufficient for the family's needs, then the wife should be innovative, namely trying to be able to change the situation. The wife or mother can take advantage of their abilities so that together with their husbands, they are able to overcome the economic problems they are facing. Thus, a mother as an element in charge of the family economy also participates because of the responsibility to change the economic situation of the family together and to maintain family resilience well (Subhan, 2015 ; 134).

In this case the researcher provides a solution so that the intestinal chip home industry women can develop even more in the intestinal chip entrepreneurship, it is important to hold trainings in order to increase knowledge about trading, make intestinal chips with many flavors, product packaging, attractive and extensive marketing. This can be applied in the businesses that have been initiated so that the business grows. Motivating one another is also important in order to remain enthusiastic in advancing their joint business and maintaining good relationships between business actors and each other.

The intestinal chips home industry in Sidowungu Village shows a big role in improving the welfare of the community because of several business activities that provide benefits to be able to increase community income, especially family income, among which the researchers concluded in the following 5 sections: 1 . Providing income for the people of Sidowungu Village especially for the income of the chicken intestine chips home industry entrepreneur. The majority of the people in Sidowungu Village depend on their livelihoods 
from selling chickens starting from chicken farm business owners, laborers, chicken retailers, and chicken intestine chips businesses. which is obtained by the people of Sidowungu Village, especially women who are entrepreneurs of chicken intestine chips, is to meet economic needs. If the sale is giving big results. Will help to meet primary, secondary and tertiary needs, 4 . Reduce Unemployment, 5 . With the large number of chicken intestine chips home industry, it can help reduce unemployment by becoming employees, especially for housewives with low education, so that it can help the family economy each.

Chicken Intestine Chips Home Industry Efforts to Increase Family Income. The home industry of making chicken intestine chips in Sidowungu Village is a business undertaken by the majority of women in Sidowungu Village. The home industry for making chicken intestine chips has very good prospects for increasing income because many home industry businesses and employees of making chicken intestine chips have stated that their family income has increased. Even though the chicken intestine chips home industry has experienced a few obstacles, such as: 1. the production process carried out by the entrepreneur is still very simple or still uses a manual system, 2. the aspect of capital is still minimal, 3. the marketing range is not very broad.

But this obstacle does not really affect the income of the chicken intestine chips entrepreneur in Sidowungu Village, meaning that their income is sufficient to meet their daily needs. According to Fuad et al $(2017 ; 133)$, income is an amount of money or something that can be measured in money, which is used to meet life needs, or for consumption. For the people of Sidowungu Village, the home industry of chicken intestine chips plays an important role in increasing family income because it is able to meet their daily needs such as meeting basic needs, being able to finance their children and being free from unemployment and reducing the burden on the husband even though the income earned is not too much like industry- large industry in general, but this is an increase in family income when viewed from a microeconomic perspective.

The Role of the Government in the Home Industry of Sidowungu Village Chicken Intestinal Chips. In general, small businesses have characteristics as weak businesses in terms of knowledge, skills, technology used, capital, and marketing. Therefore, small businesses such as home industries need to be empowered to be able to compete and be independent. However, in the home industry for intestinal chips in Sidowungu Village, the government does not play a role in all types of assistance, starting from capital, assistance with technology tools and capacity training. This is evident in the results of research conducted by researchers on household industry players that assistance from the Government has not been felt by the intestinal chips home industry players to date.

\section{CONCLUSION AND SUGGESTIONS}

Based on data analysis in this study, it can be concluded about the Role of Chicken Intestinal Chips Home Industry in Increasing Family Income (study of chicken intestine chips home industry in Sidowungu Village, Menganti District, Gresik Regency, East Java):

- Chicken intestine chips business activities are able to expand employment and provide broad economic services to the people of Sidowungu village and play a role in increasing family income, reducing unemployment and improving community welfare;

- The home industry of chicken intestine chips in the village of Sidowungu is experiencing several constraints;

- The role and support of the Government for the chicken intestine chips home industry in Sidowungu Village has not been felt by all entrepreneurs.

The government should increase its role in the chicken intestine chips home industry as an effort to increase family income and.

- The owner of the chicken intestine chips business should be even more active in increasing the value of production, applying the capital and labor used in order to be able to create high production value; 
- For further research with similar topics, it is recommended to conduct further studies by conducting socialization for intestinal chips business owners in Sidowungu Village to register their food business with the Health Office in each region (Regency or Province) in order to obtain a PIRT (Home Industry Food).

\section{REFERENCES}

1. Badan Pengawasan Obatan and Makanan Republik Indonesia (BPOM RI). jdih.pom.go.id.

2. Badan Pusat Statistik (BPS) 2017. http://www.bps.go.id.

3. Fattah, M and Pudji Purwanti. 2017. Manajemen Industri Perikanan. Malang: UB Press.

4. Fuad, M, Siti Nurbaya and Amirullah (2017). Pengantar Bisnis. Yogyakarta: Penerbitan Indomedia Pustaka.

5. Idris, Amiruddin. (2016). Pengantar Ekonomi Sumber Daya Manusia. Yogyakarta: CV.Budi Utama.

6. Kimbal, Rahel Widiawati (2015). "Modal sosial and ekonomi industri kecil: sebuah studi kualitatif". Ed.1, cet. 1. Yogyakarta: CV. Budi Utama.

7. Lubis, Amany. (2018). Ketahanan Keluarga dalam Perspektif Islam. Jakarta:

8. Pustaka Cendekiawan.

9. Rahardja, Pratama. (2010). Pengantar Ilmu Ekonomi (Mikroekonomi \& Makroekonomi). Jakarta: Lembaga Penerbit FEUI.

10. Rifai, Melly Sulastri Sri. (2010). Ekonomi Keluaraga. Bandung: TKTP.

11. Sugiyono (2017). Metode Penelitian Kuantitatif, Kualitatif, and R\&D. Bandung: ALFABETA.

12. Supriyono, R,A (2018). Akutansi Keprilakuan. Yogyakarta: Gadja Mada University Pres.

13. Sattar (2018). Buku Ajar Perekonomian Indonesia. Yogyakarta: CV. Budi Utama.

14. Sattar (2018). Buku Ajar Teori Ekonomi Makro. Yogyakarta: CV. Budi Utama.

15. Undang-Undang Negara Republik Indonesia No 03 Tahun 2014 tentang perindustrian. 